УДК 519.78

\title{
System Dynamics Model for Conversion to Organic Farming
}

\author{
Črtomir Rozman* \\ Faculty of Agriculture and Life Sciences \\ University of Maribor \\ Pivola, 10, SI-2311 Hoče \\ Slovenia \\ Miroljub Kljajić \\ Andrej Škraba $\ddagger$ \\ Cybernetics \& Decision Support Systems Laboratory \\ Faculty of Organizational Sciences \\ University of Maribor \\ Kidričeva cesta, 55a, SI-4000 Kranj
}

Slovenia

Received 12.11.2014, received in revised form 10.12.2014, accepted 27.12.2014

In this paper model for organic farming development to support government decision making is presented. After performing several simulation scenarios we discovered that conversion to organic farming relies on subsidies which provide the main motivation for conversion from conventional farming to organic farming. However, the subsidies are not the only driving force in the system, even more important are activities that promote organic farming, since sufficiently large subsidies could not be provided in order to complete the conversion from conventional to organic farming to the extent desired. Another important feature is food demand, determined by population size, which negatively influences the conversion to organic farming due to the increased demand leading to increased food prices.

Keywords: system dynamics, organic farming, simulation, model.

\section{Introduction}

Bontkes and Van Keulen [1] argue that the study of agricultural systems requires the use of non-linear dynamic models that allow the simulation of the system in a qualitative way, based on a description of the underlying processes. Their approach is illustrated with a regional model that has been developed to simulate agricultural development in the Koutiala region in the southwestern part of Mali. There are many factors, such as farm type and soil quality, which might influence farmers' decisions. However, attempting to consider the complex interactions of all factors, the authors [2] have adopted the approach of isolating parts of a system and examining them individually, while assuming that all other things are equal. In their research, the diffusion of organic farming practices is modeled by a generic agent model, based on the theory of planned behavior [3], for understanding and modeling the farmer's decision-making process. Darnhofer et al. [4] study reasons for converting to organic farming with the use of a decision tree that

\footnotetext{
*crt.rozman@um.si

${ }^{\dagger}$ miroljub.kljajic@fov.uni-mb.si

$\ddagger$ andrej.skraba@fov.uni-mb.si

(c) Siberian Federal University. All rights reserved
} 
has been tested with survey data, while the complete overview of modeling approaches in the area of organic farming is provided by [5]. The detailed analysis of organic farming development scenarios is provided by Zanoli et al. [6] and Zanoli et al. [7].

Besides econometric modeling and mathematical programming, other approaches can also be used for the modeling of agricultural systems. System dynamics (SD) methodology [9] can be used as an alternative for modeling policy scenarios $[8,15,17]$. In particular, SD methodology has an advantage in cases in which it should be considered that [6]: organic farmings future development prediction is a difficult task, given the almost total lack of time series data for the sector. In such cases, scenarios may be considered as hypothetical images of the future evaluated on the SD based models. In that case, the SD model combined with different scenarios could be a useful explanatory tool for policy analyses for experts. The most significant work in the field of simulation of development policy scenarios is presented by Shi and Gill [16] who developed an SD-based simulation model for ecological agriculture development for Jinshan County (China); and by study [11] where authors developed an integrated system dynamics model for development in the Canary Islands, where interactions between agriculture, population, industry and ecology were taken into consideration. The preliminary investigations into SD simulation of organic farming development have been conducted by Rozman et al. [13,12]. The model incorporates key variables affecting organic farming systems and is used to identify the main reasons that the strategic goal (15\% per cent of organic farms) has not been achieved; this research did not include all aspects of the food market and consumer factors [12]. However, consumer concerns are inherently dynamic because they respond to complex societal and technological situations and developments. For example, because of rising concerns about global warming, the carbon dioxide absorption of crops is now attracting public attention, which means that new requirements are being proposed for the environmentally friendly production of crops.

This paper presents a system dynamics model for the development of organic agriculture in Slovenia in order to identify key variables that determine conversion dynamics and to propose development policy in order to achieve strategic goals as set in the strategic document called Action Plan for the Development Organic Farming (ANEK) [19]. The paper is organized as follows: first, we present the basics of system dynamics methodology; this is followed by system analysis and identification of key variables, showing the main flows and feedback loops within the system. The results section presents scenarios (different policies in organic farming) and their evaluation through the application of the developed SD model. The main findings and suggestions for further study conclude the article.

\section{Methodology}

This study is based on system dynamics methodology. The fundamentals of system dynamics were defined by [9] as a method for the modeling of industrial dynamics. In the early 1980s, at the beginning of the Information Age, the method was renamed as System Dynamics (SD). The idea of this modeling is based on the assumption that every real system, as well as any business system, could be described by a system of equations that represent interconnected flow or Rates and Stocks i.e. Levels.

Fig. 1 provides an example of the symbolic representation of described elements, in which $L$ represents the Level (stock), $R_{\text {in }}$ the input flow, $R_{\text {out }}$ the output flow and $P_{1}$ and $P_{2}$ some arbitrary parameters. One of the common elements is an element representing the Auxiliary expression ( $A_{1}$ and $A_{2}$ in Fig. 1) by which one expresses the arithmetic relations between $L, R$ 
and $P$. Each level, $L$, or state element, has its own input rate, $R_{i n}$ and its own output rate, $R_{\text {out }}$. In Fig. 1, $P_{1}$ and $P_{2}$ represent the decision parameters by which the flows are regulated

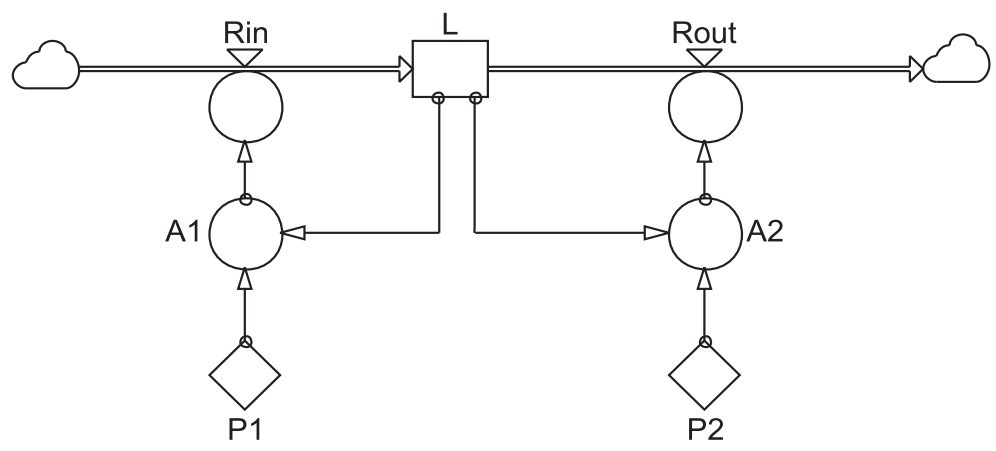

Fig. 1. Basic elements in System Dynamics

via the auxiliary elements $A_{1}$ and $A_{2}$. The clouds at the beginning and at the end represent the environment of the model. This is, therefore, our boundary for the modeling of the addressed model. From the formal viewpoint, this method is indeed straightforward and clear, as well as understandable. In the case of a concrete problem, the possible meaning of the $L$ and $R$ elements are obtained. The conservation-of-mass principle for the above model could be described with the dynamics equation in the form of difference equation:

$$
L(k+1)=L(k)+\Delta t\left(R_{\text {in }}(k)-R_{\text {out }}(k)\right) \quad k=0,1,2, \ldots, n
$$

in which $k$ represents discrete time, $\Delta t$ is the time interval of computation. Each entrepreneur understands that the value of Level element $L(k+1)$ increases if $R_{\text {in }}(k)>R_{\text {out }}(k)$; it is unchanged if $R_{\text {in }}(k)=R_{\text {out }}(k)$, and decreases if $R_{\text {in }}(k)<R_{\text {out }}(k)$. The method for problem solving with the use of system dynamics methodology is similar to that used with the systems approach, and can be described as a synthesis of the following steps [10]:

- definition of the problem,

- setting objectives,

- drafting the study,

- formulation of a mathematical model,

- developing a computer program,

- model validation,

- preparation of the experiment (simulation scenario),

- simulation with analysis of results.

In this study, we followed these steps to develop the simulation model of organic farming development, which will be presented in detail. Several scenarios were prepared and tested on the model in order to determine the impact of changes in key parameter values. 


\section{The system dynamics model and analysis of the organic agriculture system}

There are approximately 80,000 farms in Slovenia, both conventional and organic. In 2006, only 1,728 farms were under the organic farm control system, equaling $2.4 \%$ of all farms in that year $(77,138)$, which is 26,831 hectares representing $5.5 \%$ of all arable area. Even though a subsidy had been offered to the farmers, the proportion of organic farms was still low, less than $5 \%$. Recent research [12] has shown that the growth of the number of organic farms slowed down despite increased subsidies. The short-term strategic goal is to reach $10 \%$, or $15 \%$, of organic farms by the year 2015. This goal is determined by the state action plan. Although the number increased to 2,000 in 2007 and 2,067 in 2008, the strategic goal of $15 \%$ has still not been achieved.

According to an analysis of state of the art organic farming, the simulation model should consider the key variables that influence the development of organic farming, which are in accordance with the previous research in this field $[6,7,13]$, such as:

- the number of conventional farms,

- the number of organic farms,

- conversion from conventional to organic farming,

- subsidies,

- the promotion of organic farming (marketing, market development, education),

- the organization of a general organic farming support environment,

- a system of self-support (self organization such as shared processing and marketing),

- the delay constants of process change (for example, an increase in one parameter causes visible consequences after a time delay),

- the aggregate food demand and supply.

A key variable in the model is the number of organic farms. These are those farms that are under the system of one of the control organizations. During the development of the Causal Loop Diagram (CLD) (Fig. 2), as the first step towards the development of the SD model, the following key variables were identified: a) the number of potential candidates (farms) for conversion to organic farming, b) the number of farms already converted to organic farming, c) the flow between a) and b) which is conversion rate (transition).

A causal loop diagram consists of variables connected by arrows denoting the causal influences between the considered variables. Each Level and Rate element has a directed arrow assigned so that one element represents the cause and the other the consequence. Directed arrows from cause to consequence have the "+" sign if the cause and consequence have the same direction and " $\mathrm{y}$ " if the opposite direction exists.

Loop B1 represents a negative loop, with a goal value of 0 (depleting the number of Conventional Farms). The number of "Conventional Farms" divided by the "Total Number of Farms" yields the "Concentration of Conventional Farms", which is initially high, meaning that there should be a high initial preference for "Conversion". "Concentration of Conventional Farms" positively influences the "Communication". This variable represents the general communication 
between the conventional approach members and the organic approach members. "Conversion" positively influences the number of "Organic Farms". If the number of "Organic Farms" increases, the "Information Spread" increases above the level that it would otherwise have been. "Information Spread" by "Organic Farms" members is positively influenced by the "Information Spread Factor", which could be, for example, increased by marketing campaigns. "Information Spread" positively influences "Communication". The number of "Conversion" is determined by the "Success Factor", which determines the "Communication Success", yielding the number of convinced conventional members that decide to make a "Conversion". Loop R1 is a reinforcing feedback loop compensated for by the initial balancing feedback loop marked with B1. If the number of "Organic Farms" increases, the "Promotion and Market Development", supported by the "Policy Support Factor", increases above the level that it would otherwise have been. Higher "Promotion and Market Development" positively influences the "Self Organization Resources", which contribute positively to the "Support Resources" on which the "Conversion" is dependent. Here, it is assumed that "Promotion and Market Development" contributes to the "Self Organization Resources", for example new processing facilities. However, it takes time to provide new facilities that would contribute to the better marketing and distribution of products.

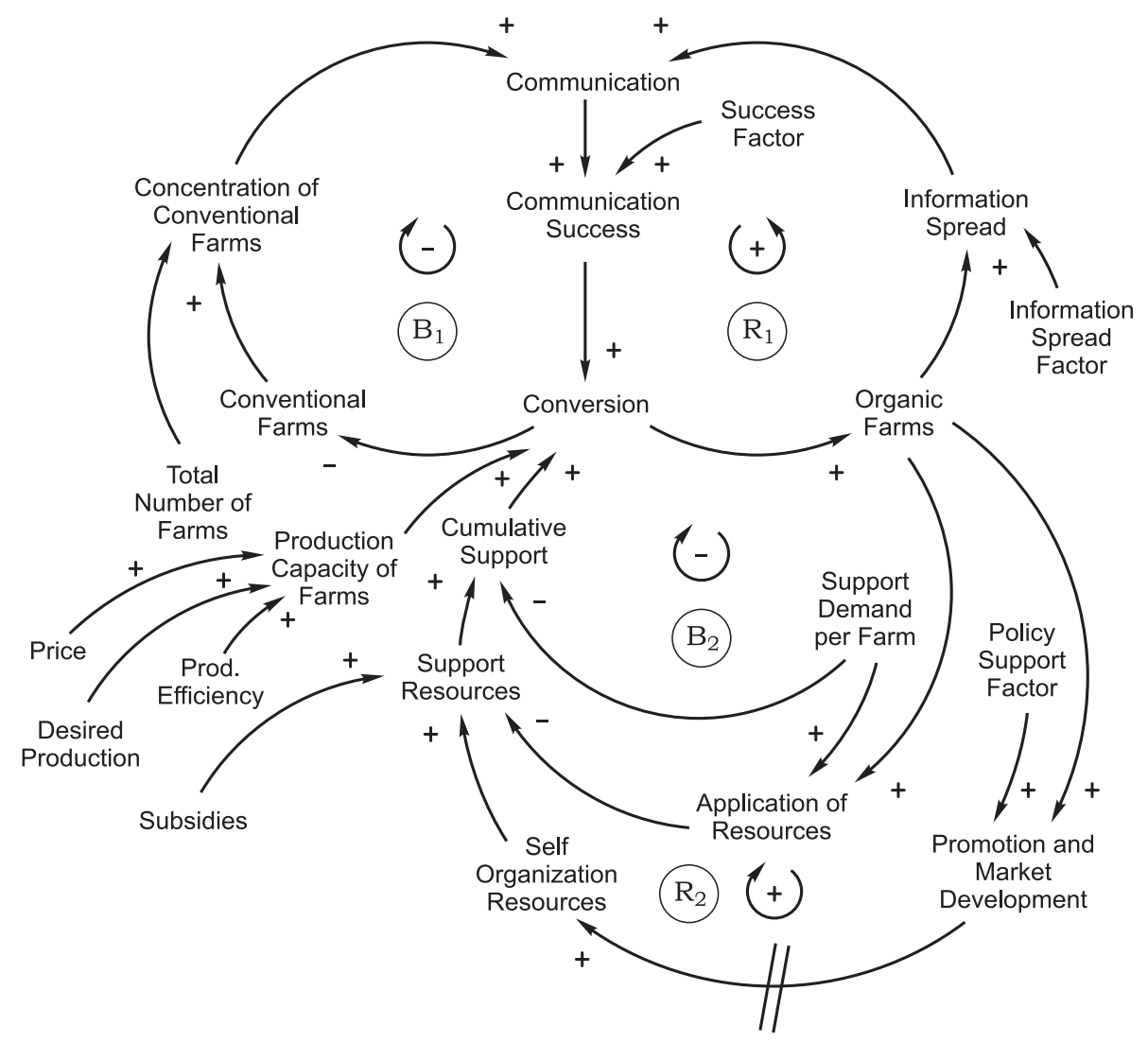

Fig. 2. Causal Loop Diagram (CLD) of system structure

There is a delay mark between the "Promotion and Market Development" and "Self Organization Resources". Long (such as two- or three-year) delays should be expected here since a significant amount of time is needed in order to promote the organic farming idea and the 
marketing channels that will support organic farming; [13]. The parameter "Delay" should be considered as the time needed for supporting actions, such as marketing and promotion, to provide proper result, i.e. increase in organic farming support resources.

The "Support Resources" are significantly dependent on the government "Subsidies" that determine the intensity of the conversion to organic farming. The interconnections marked with "R2" have the characteristic of reinforcing feedback loops. According to government policy, the growth in the number of "Organic Farms" should be properly supported in order to promote an increase in self-organization of, for example, organic food marketing and promotion. Thus, the reinforcing feedback loop R2 should serve as a growth generator in the system.

Loop B2 represents a balancing loop. If the number of "Organic Farms" increases, the "Application of Resources" increases above the level that it would otherwise have been. The "Application of Resources" is also dependent on the resources needed per farm i.e. "Support Demand per Farm". Higher "Application of Resources" can cause the depletion of the "Support Resources". The conversion is dependent on the "Support Demand per Farm" and "Application of Resources". If more resources are needed per farm, fewer organic farms can be supported, and therefore lower numbers of "Conversion" should be expected. In considering a real case, the negative loops B1 and B2 are dominant, leaving the system in an undesirable state of equilibrium. This would mean that the number of organic farms is constant and well below the desired level. In order to move the system away from the equilibrium, one should consider the policies that would raise the impact of the reinforcing feedback loops R1 and R2, which should move the system state, i.e. the number of "Organic Farms", to the higher equilibrium values. "Price", "Desired production" and "Production efficiency" are also key factors that impact the intensity of the transition.

\section{Model development}

A system dynamics model structure is shown in Fig. 3. The model consists of 36 variables and 60 links. There are two levelelements applied in the upper part of the model: The variable "Conventional farms" represents the number of conventional farms. By the flow "Conversion" the "Conventional" farms" become "Organic farms". This structure is commonly known as the market absorption model. "Conversion" is dependent on the "Support resources" available, modeled as a level element that actually determines the goal value of the organic farms. The desired conversion can only be achieved if there are enough "Support resources" present in order to make a "Conversion". The "Support resources" are not only the financial means. Here, the support of society is also considered; for example, education should create positive attitudes in relation to organic farming. In this category, the market development, as well as the demand, should also be considered. However, at present the "Support resources" are mainly dependent on subsidies from the government. The key variable "Self organization resources" is driven by the impact of the policy and the level of societal support, which will intensify with increasing numbers of "Organic farms". This represents the application of a reinforcing feedback loop that should be augmented. The "Development limit" represents the function of the variable consumption of resources. If the resources are scarce, the usage is lower than in the case of abundance. Resources are consumed by the "Organic farms". The prosperity of the "Organic farms" therefore depends on the "Support resources", which are not only financial means; here, the social impact of organic farming represents the supportive environment that should sustain such an activity, which in the world of consumption is counterintuitive [9]. "Conversion" is also dependent on the total food 
production and "Food demand". In our case, the effect of prices to the conversion is considered by the empirical function captured in the "Transition Function Based on Production", which limits the conversion if the overall supply falls under desired level of food production. What is noteworthy here is that one could not expect that the conversion would be made if the food supply falls under particular level. It has been proven that conventional production is higher than organic production; however, this depends on the crop considered. Lower productivity of organic farming was therefore considered in the model. The model addresses a situation in which the imports and exports are stable and concentrates on the relations between selected variables. The model that would take in the consideration imports and exports would be significantly more complex, and it is out of scope of the present research.

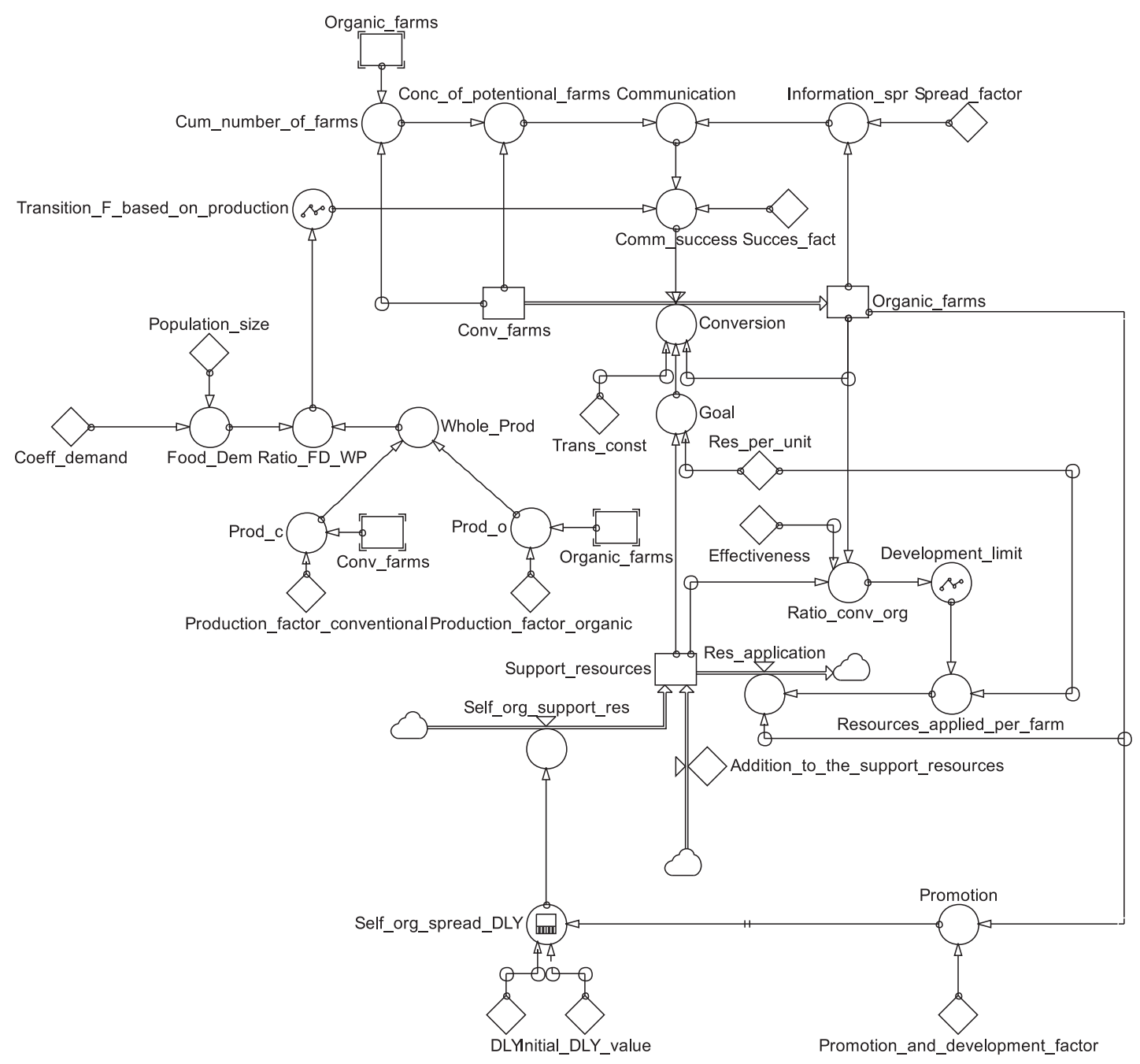

Fig. 3. SD model of Organic Farming Development 


\section{Results and discussion}

The model is used in order to simulate different scenarios that enable assessment of policy scenarios with respect to development of organic farming. Tab. 1 shows input parameters for 7 scenarios simulated. The main policy parameter beeing changed are subsidies. Scenario analysis is a qualitative tool for strategic policy analysis that enables researchers and policymakers to support decision making, and a systemic analysis of the main determinants of a business sector [7]. $\mathrm{SC} 1$ is the initial scenario in which the initial amount of the subsidy provided is 2000, i.e. that there are sufficient resources provided by subsidy to support 2000 organic farms.

Table 1. Parameters of simulation scenarios

\begin{tabular}{cccccc}
\hline Conversion & Subsidies & $\begin{array}{c}\text { Coefficient of } \\
\text { food demand }\end{array}$ & DLY & Promo. factor & Population \\
\hline 1 & 1750 & 1.25 & 18 & 0.8 & $2 \mathrm{M}$ \\
2 & 1750 & 1.15 & 18 & 0.8 & $2 \mathrm{M}$ \\
3 & 3500 & 1.15 & 18 & 0.8 & $2 \mathrm{M}$ \\
4 & 3500 & 1.15 & 18 & 2 & $2 \mathrm{M}$ \\
5 & 3500 & 1.15 & 18 & 2 & $2 \mathrm{M}$ \\
5 & 3500 & 1.15 & 42 & 2 & $2 \mathrm{M}$ \\
7 & 3500 & 1.15 & 42 & 2 & $2.1 \mathrm{M}$ \\
\hline
\end{tabular}
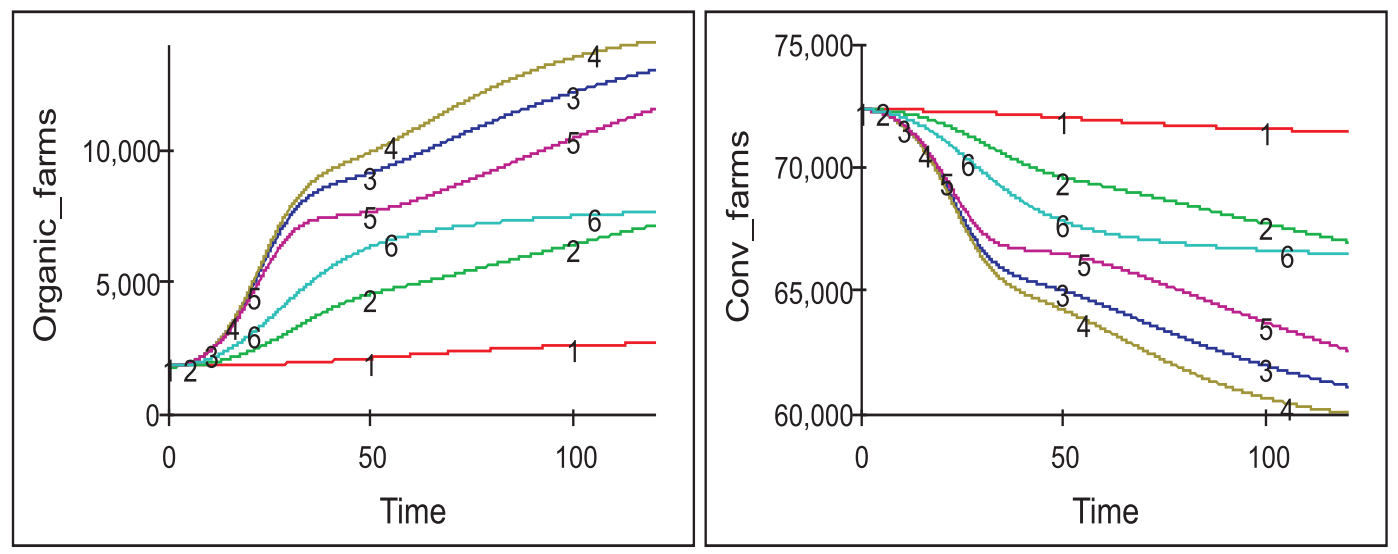

Fig. 4. Number of organic and conventional farms

Scenarios (Fig. 4 and 5) SC1, SC2 and SC3 represent the increase of the subsidies and the impact on the transition rate. Scenario 4 shows the impact of the increased promotion factor, which would yield the higher limit conversion to the organic farming. Impact of the increased delay in the providing self-support resoures is shown by the scenario 5 . Here one assumes, that this delay is increased from two to four years on average. Scenario 6 represents the increase in the population which would lead to the status Quo in the number of Organic and Conventional farms. It is supposed, that the tranistion in this case would not occur due to the increased food demand. In this case the negative conversion could also be considered however, this is the 

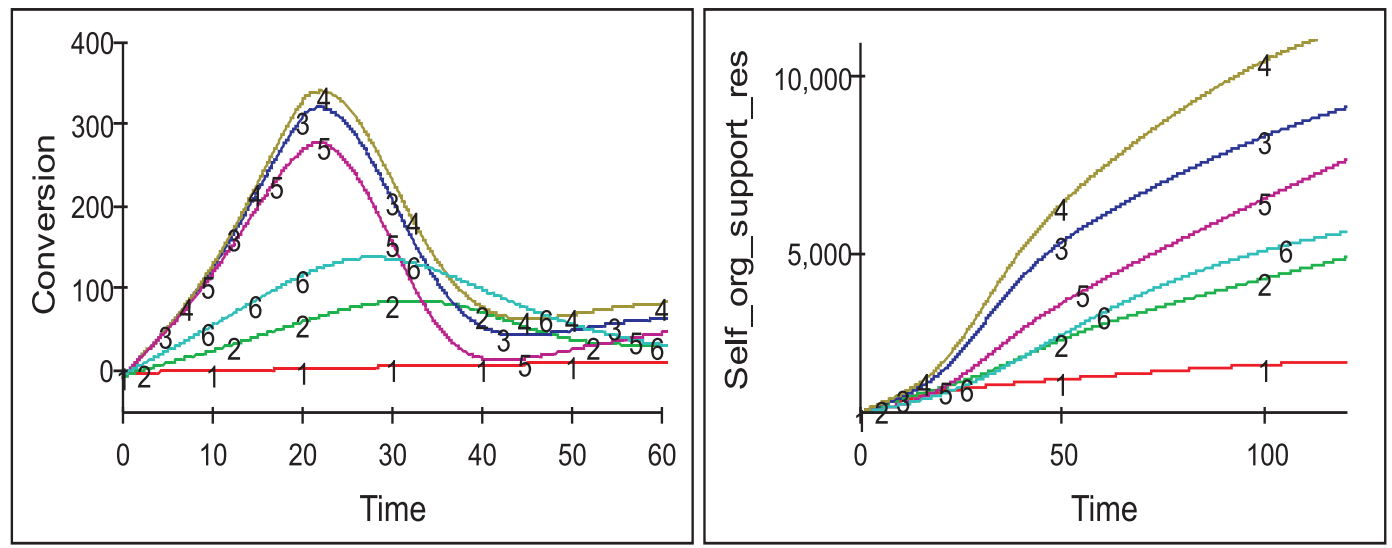

Fig. 5. Conversion dynamics

limitation of the proposed model. Scenario 7 shows the transition to the organic farming if the Coefficient of food demand would decrease; this would be the case if for example the imports of the food would be increased.

\section{Conclusion}

Conversion to the organic farming relies on subsidies which provide the main source of conversion from conventional farming to organic farming. However, the Subsidies are not the only driving force in the system; even more important are other activities that promote organic farming. Subsidies could not be provided in sufficient amount in order to complete conversion from the conventional to organic farming. Feasible strategy to achieve complete conversion should consider reinforcing feedback loop between resources, number of organic farms and supportive actions which are bounded to the number of organic farms. Current output parameter i.e. number of organic farms, is caught in an unwanted equilibrium value due to the domination of balancing feedback loops in the system. Important factor is self-organization of the organic farming environment which includes market development and general public awareness.

This research has been financed by the Slovenian Research Agency ARRS, Targeted Research Projects Framework, Program CRP V7-1018.

\section{References}

[1] T.S.Bontkes, Van H.Keulen, . Modelling the dynamics of agricultural development at farm and regional level, Agric. Syst., 76(2003), no. 1, 379-396.

[2] P.Kaufmann, S.Stagl, D.W.Franks, Simulating the diffusion of organic farming practices in two New EU Member States, Ecol. Econ., 68(2009), 2580-2593.

[3] I.Ajzen, The Theory of Planned Behavior, Orga. Behav. Hum. Decis. Proc., 50( 1991), no. 2, 179-211.

[4] I.Darnhofer, W.Schneeberger, B.Freyer, Converting or not converting to organic farming in Austria: Farmer types and their rationale, Agric. Human Values, 22(2005), 39-52. 
[5] A.Acs, P.B.M.Berentsen, R.B.M.Huirne, Modelling conventional and organic farming: a literature review, Wageningen Journal of Life Sciences, 53(2005), no. 1, 1-18.

[6] R.Zanoli, D.Gambelli, D.Vairo, Organic Farming in Europe by 2010: Scenarios for the future. Stuttgart-Hohenheim, 2000.

[7] R.Zanoli, D.Gambelli, D.Vairo, Scenarios of the organic food market in Europe, Food Policy, 37( 2012), 41-57.

[8] A.Elshorbagy, A.Jutla, L.Barbour, System dynamics approach to assess the sustainability of reclamation of disturbed watersheds, Can. J. Civ. Eng., 32(2005), no. 1, 144-158.

[9] J. W.Forrester, Industrial Dynamics: A Major Breakthrough for Decision Makers, Harv. Busin. Rev., 36(1958), no. 4, 37-66.

[10] J. W.Forrester, System dynamics, systems thinking, and soft OR, Syst. Dynam. Rev., 10(1994), no. 2-3, 245-256.

[11] M.Kljajic, C.A.V.Legna, A.Skraba, J.Peternel, Simulation Model of the Canary Islands for Public Decision Support y Preliminary Results, Proceedings of the 20th International Conference of the System Dynamics Society; The System Dynamics Society, Albany, New York, ZDA 2003.

[12] C.Rozman, K.Pazek, M.Kljajic, M.Bavec, J.Turk, F.Bavec, Turk, A.Skraba, The dynamic simulation of organic farming development scenarios - A case study in Slovenia, Computers and Electronics in Agriculture, 96(2013), 163-172.

[13] C.Rozman, A.Skraba, M.Kljajic, K.Pazek, M.Bavec, F.Bavec, The system dynamics model for development of organic agriculture. 8th International Conference on Computing Anticipatory Systems, Liege, Belgium, 2007.

[14] C.Rozman, K.Pazek, M.Bavec, F.Bavec, J.Turk, D.Majkovic, The Multi-criteria analysis of spelt food processing alternatives on small organic farms, J. Sustain. Agric., 28(2006), no. $2,159-179$.

[15] A.K.Saysel, Y.Barlas, Y O.enigun, Environmental sustainability in an Agricultural development project: a system dynamics approach, J. Envi. Manag., 64(2002), 247-260.

[16] T.Shi, R.Gill, Developing effective policies for the sustainable development of ecological agriculture in China: the case study of Jinshan County with a system dynamics model, Ecol. Econ., 53(2005), 223-246.

[17] A.Skraba, M.Kljajic, R.Leskovar, Group exploration of system dynamics models - Is there a place for a feedback loop in the decision process? Syst. Dynam. Rev., 19(2003), no. 3, 243-263. ,

[18] Statistical office ot the Republic of Slovenia SORS, 2011. Organic farming, Slovenia, 2010 - final data. Available at: http ://www.stat.si/eng/novicaprikazi.aspx?id $=4080(27$ January 2012).

[19] M.H.Majcen, S.Jurcan, Action Organic Farming Development Plan in Slovenia to Year 2015 (ANEK), Government of Republic of Slovenia, 2006. 


\section{Модель системной динамики перехода к органическому земледелию}

\section{Чртомир Розман \\ Миролюб Кляйич \\ Андрей Шкраба}

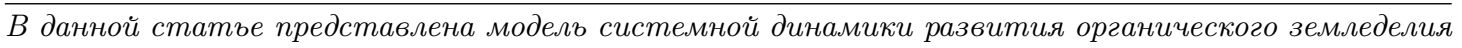
для поддержки принятия правительственных решений.

Въполнив имитационное моделирование в соответствии с несколькими различными сценариями, мы установили, что переход к органическому селъскому хозяйству определяется в основном субсидиями, которые обеспечивают основную мотивацию при преобразовании обычного сельского хозяйства в органическое земледелие.

Однако субсидии не являются единственной движущей силой в этой системе - более важнь организационные усилия по продвижению органического земледелия, так как невозможно обеспечить достаточно большие субсидии для успешного завершения перехода к органическому земледелию в желаемом объеме. Еще одним важным свойством является спрос на продовольствие, определяемый численностью населения, который отрицательно влияет на переход к органическому земледелию из-за его возрастания, ведущего к росту иен на продовольствие.

Ключевые слова: системная динамика, органическое земледелие, имитационное моделирование. 